Proceedings

\title{
Abundance and Diversity of Ambrosia Beetles (Curculionidae: Scolytinae) Influenced by the Vegetation Composition and Temperature in Brazil ${ }^{+}$
}

\author{
Caroline Vaz *, Fernando Ribeiro Sujimoto ${ }^{2}$, Hugo Leoncine Rainho, Camila Moreira Costa and \\ Juliano Gil Nunes Wendt
}

Citation: Vaz, C.; Sujimoto, F.R.; Rainho, H.L.; Costa, C.M.; Wendt, J.G.N. Abundance and Diversity of Ambrosia Beetles (Curculionidae: Scolytinae) Influenced by the Vegetation Composition and Temperature in Brazil. Proceedings 2021, 68, x.

https://doi.org/10.3390/xxxxx

Academic Editor: Caroline Vaz

Received: date

Accepted: date

Published: date

Publisher's Note: MDPI stays neutral with regard to jurisdictional claims in published maps and institutional affiliations.

Copyright: (C) 2021 by the authors. Submitted for possible open access publication under the terms and conditions of the Creative Commons Attribution (CC BY) license (http://creativecommons.org/licenses/by/4.0/).
1 Department of Agriculture, Biodiversity and Forests, Universidade Federal de Santa Catarina; e-mail@e-mail.com

2 Department of Entomology and Acarology, Universidade de São Paulo; fsujimoto@gmail.com

* Correspondence: caroline-vaz@outlook.com.br; Tel.: +55-(49)998292763

+ Presented at the 1st International Electronic Conference on Biological Diversity, Ecology and Evolution, 1531 March 2021; Available online: https://bdee2021.sciforum.net/.

\begin{abstract}
Bark and ambrosia beetles are considered the main forest pest groups and also biological indicators in natural areas, due to their especial participation in wood rot process. However, there are few investigations exploring the aspects related to the temperature influence, as well as the host plant availability along the geographical distribution, abundance and diversity of these beetles in anthropized areas. Thus, we aimed to access such parameters to Scolytinae in three different anthropized environments in the south of Brazil and verify their possible correlation with temperature and distinct host plants. It was installed flight interception alcohol traps to monitor the beetles. The experimental areas were divided in uncovered soil area with grass fragments; reforestation area composed exclusively to Mimosa scabrella, a native plant from south of Brazil; agroforestry system with native and exotic plant species. It was collected 357 Scolytinae individuals, distributed in 6 tribes, 15 genus and 42 species. Individuals from the Corthylini tribe dominated in abundance ( 78\%) and diversity (24 spp.). From this group, $\sim 58 \%$ from all species belong to Corthylus. We also observed a correlation between the temperature and Scolytinae abundance, since the higher number of species were collected during the lowest temperatures. The abundance and diversity similarity between M. scabrella and the agroforestry areas demonstrated that a higher diversity of plants does not indicate a higher diversity of ambrosia beetles. Therefore, in anthropized areas, the Corthylini beetles do not seem to be potential bioindicators, which can be related to their polyphagous ability.
\end{abstract}

Keywords: anthropized areas; beetles ecology; Mimosa scabrella; bioindicators

\section{Introduction}

Bark and ambrosia beetles (Curculionidae: Scolytinae) constitute the main group of forest pests worldwide, well-known by their adaptation to different habitats. In addition to their economic importance, these insects are ecologically relevant due to the wood degradation, providing nutrient cycling, as well as occupying a biological indicators position of environmental conservation (WOOD, 2007) [8].Bark beetles are phyllophages, that is, they feed on the host's dead tissues in the vast majority of the nutrient-rich phloem. Adults and larvae build their tunnels while feeding and walking on the bark. The ambrosia beetle, on the other hand, creates its gallery, usually inside the sapwood of the dead or stressed host due to some biotic and/or abiotic factor, it feeds and cultivates the symbiotic fungus known as ambrosia (HULCR, 2007) [3]. In addition, there is a third feeding habit called myelophages, which feed and reproduce in the marrow of small stems (WOOD, 2007) [8]. 
Despite their remarkable ecological importance, both groups are not deeply explored over the perspective of temperature influence and availability of native and exotic host plants on the geographic distribution, abundance and diversity of their different guilds. The elucidation of how the temperature and host plants affect the ecological parameters of these beetles can bring a sufficiently robust database to provide information on how human activities, as agriculture expansion and climate change, are interfering with the fauna and flora of certain places. In addition, some species may become rare and disappear, and others have a tendency to dominate the environment, this behavior may be related to natural or anthropogenic factors in the vegetation (SILVA, et al. 2020) [7].

Miller and Rabaglia (2009) [5] carried out a study with flight traps baited with semiochemicals to compare the beetles attraction between two compounds, ethanol and $\alpha$-pinene. Thus, using such methodology, it became possible to detect and monitor bark and ambrosia beetles in the southeast from the USA. Due to their results and from other authors, therefore, ethanol traps became a classical and useful way to attract and collect several species of Scolytinae, reinforcing the importance of monitoring using this type of trap.

Based on the above, we aimed to access the abundance and diversity of Scolytinae in three environments of the mixed ombrophilous forest in the south of Brazil, and to verify the existence of a possible correlation between these ecological data, with temperature and presence of different host plants.

\section{Experiments}

The present study was carried out in two forest formations, (a) one consisting of $\mathrm{Mi}$ mosa scabrella (Benth.) plantation and the other (b) an agroforest system area. For comparative purposes, (c) an open field area was also assessed. The three points are inserted in the coverage area of the Federal University of Santa Catarina, Curitibanos, $27^{\circ} 17^{\prime} 05^{\prime} \mathrm{S}$ $50^{\circ} 32^{\prime} 05^{`} \mathrm{~W}$. The climate of the region, according to Köppen classification, is considered mesothermic humid subtropical (WREGE et al., 2011) [9].

The area formed exclusively by the native tree M. scabrella is between 9 and 10 years old. Such plants were introduced by seed dispersal and natural regeneration. Any silvicultural interventions were not carried out in the area, such as pruning, weeding, fertilizing, thinning or cutting. The tree where the trap was positioned was $4 \mathrm{~m}$ away from the border of the plantation and has a BHD of $61 \mathrm{~cm}$.

The agroforest system was composed by yerba mate (Ilex paraguariensis), as well as the fruit species Eugenia uniflora (L.), mountain guava (Acca sellowiana), and Eugenia involucrata. The area also presented crop rotations, with corn and cassava during the summer, and ryegrass (Lolium multiflorum) and oats (Avena sativa L.) during the winter (BARBOSA et al., 2017) [1].The trap was installed on I. paraguariensis, which is between 7 and 8 years, $3 \mathrm{~m}$ high with the BHD of $29 \mathrm{~cm}$. The tree was $4 \mathrm{~m}$ away from the border. The open field area was composed by only one $M$. scabrella tree, in which the trap was placed, being an open area with no specific plantation.

For the beetles attraction and collection, it was used flight interception traps model Carvalho-47. One trap was installed in each formation, all positioned $1.30 \mathrm{~m}$ from the ground level. The number of traps in each evaluated area is the same used by Castro (2009) [2]. The trap was made of a transparent two-liter plastic bottle, vertically fixed with the neck facing down, holding it in a collection bottle. The openings for the beetles access were vertically and opposite positions made. As an attractive bait, the collection container was filled with $96 \%$ ethanol, which acted as both an attractive and a preservative for the captured insects. The bait was replaced every two weeks after the collection of insects, totaling 18 collections. The collection intervals, can be weekly or fortnightly, depending on the attraction used. Voucher specimens were assembled and identified, afterwards. Images of two individuals per species were taken, with the leica M205C stereomicroscope equipment. 


\section{Results}

Fifteen families of the coleopteran order were collected, representing a total of 688 specimens. 95 morphospecies were counted, of which 26 were identified in species level. Regarding the number of species and individuals captured, those of the Scolytinae subfamily predominated, with 357 individuals (Figure 1), distributed among six tribes, 15 genera and 42 species. The tribes are: Corthylini- Corthylus (11 morphospecies), Corthylocurus (1 morphospecies), Amphicranus (1 morphospecies), Tricolus (6 morphospecies), Monarthrum (4 morphospecies); tribe Xyleborini- Xyleborus (2 morphospecies), Xyleborinus (2 morphospecies), Cnestus (1 morphospecies); tribe Cryphalini- Hypothenemus (3 morphospecies), Cryptocarenus (2 morphospecies), Periocryphalus (1 morphospecies); tribe Micracidini-Hylocurus (3 morphospecies); tribe Phloeosinini-Chramesus (2 morphospecies); tribe Bothrosternini- Cnesinus (1 morphospecies), Bothrosternus (1 morphospecies).

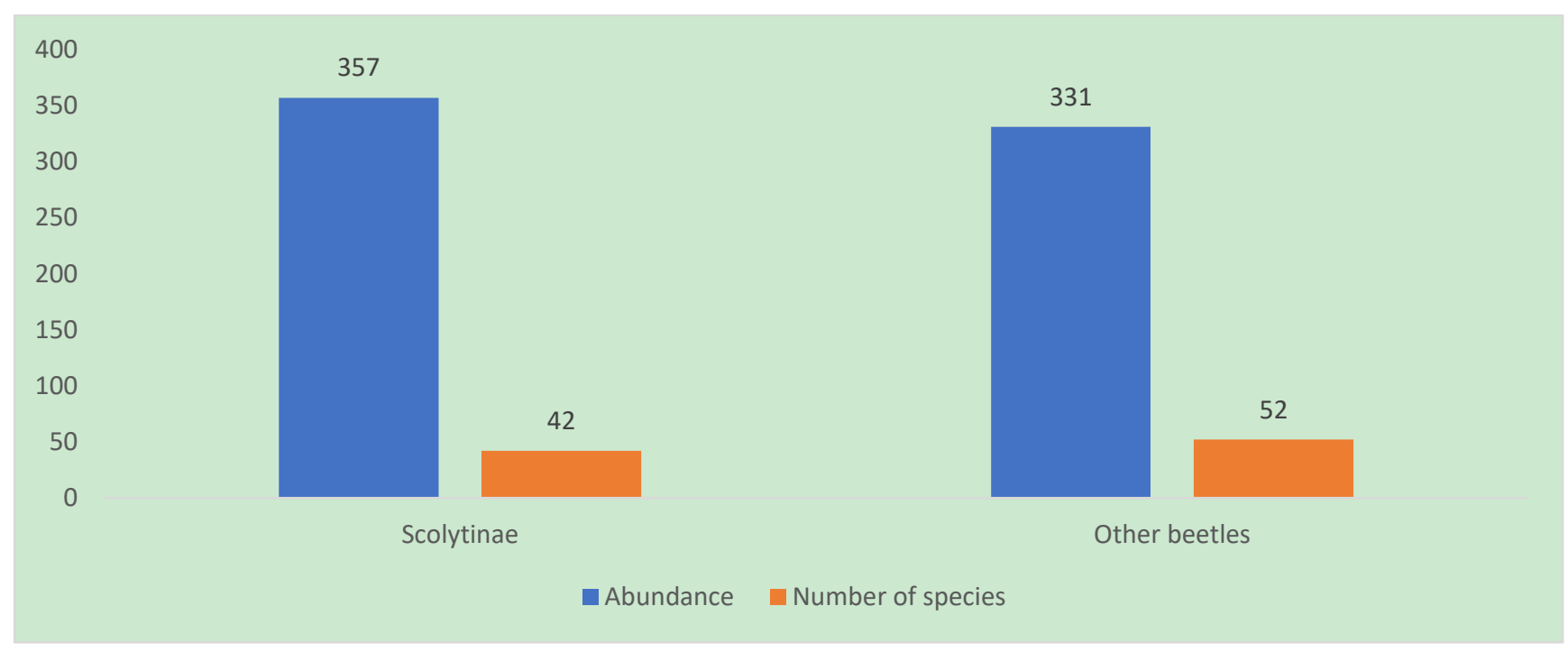

Figure 1. Abundance and number of species of Scolytinae and other beetles.

Regarding to feeding habits, it was collected 315 specimens, 8 genera and 29 species of xylomycetophagous individuals from Scolytinae (commonly called "ambrosia beetles"), approximately $89 \%$ of the total specimens from such subfamily (Figure 2 ). The rest of the collected specimens (42 specimens) were represented by the xylophagous ( 3 morphospecies, 7 species), sandflies and myelophages (10 morphospecies, 35 specimens). Individuals of the Corthylini tribe predominated both in abundance ( 279 specimens or $\sim 78 \%$ of the total) and in diversity (24 spp.). From these, 206 specimens ( $\sim 58 \%$ of the total) corresponded only to the genus Corthylus. 


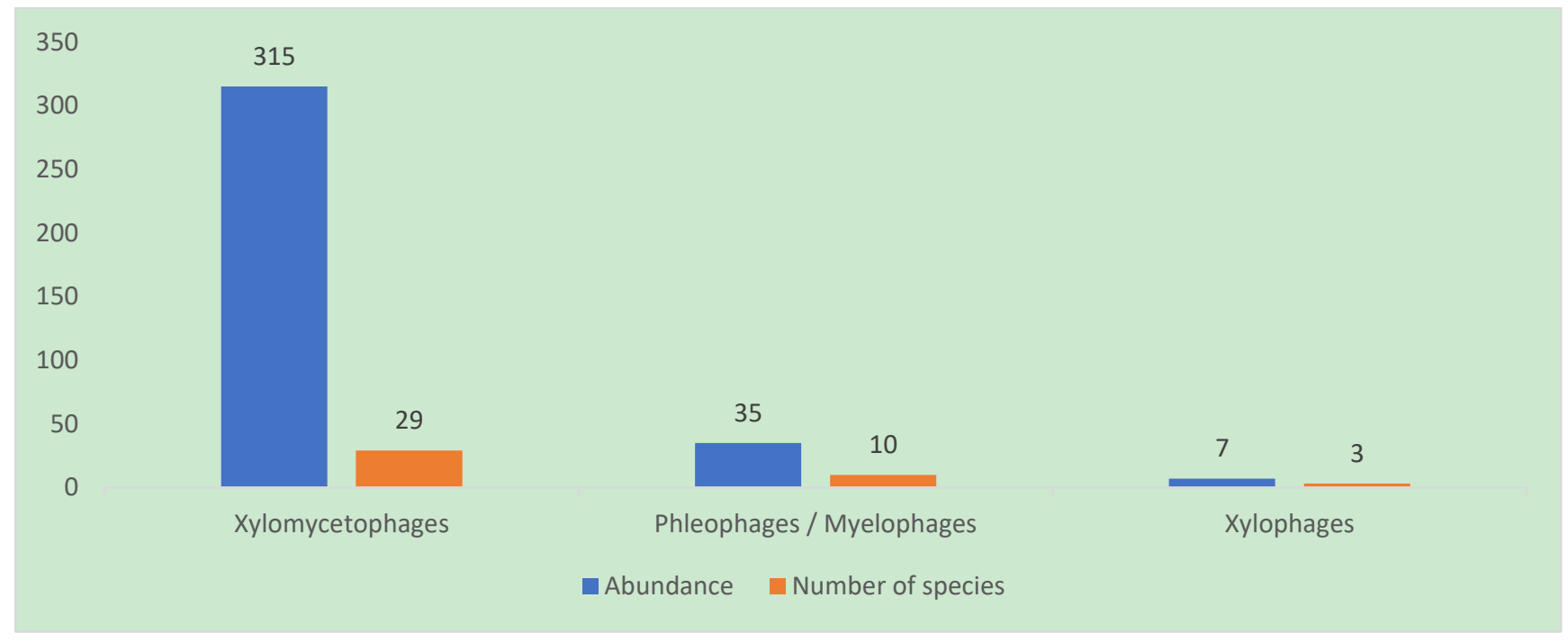

Figure 2. Scolytinae eating habits in relation to abundance and number of species.

There was no significant difference between abundance and diversity when compared M. scabrella and agroforest system areas. However, some species which are considered rare or little attracted to ethanol occurred exclusively in the former $(8 \mathrm{spp}$.) and the second area (6 spp.), respectively. There was a significant linear correlation between the temperature and abundance of Scolytinae, considering all plant formations combined, so that in winter, that is, the occurrence of low temperatures, there was a greater number of captured specimens (Figure 3). Where in graph 3, C refers to the open field, AS is the agroforestry system and MS is the bracatinga plantation. The acronym $\mathrm{T}$ refers to temperature.

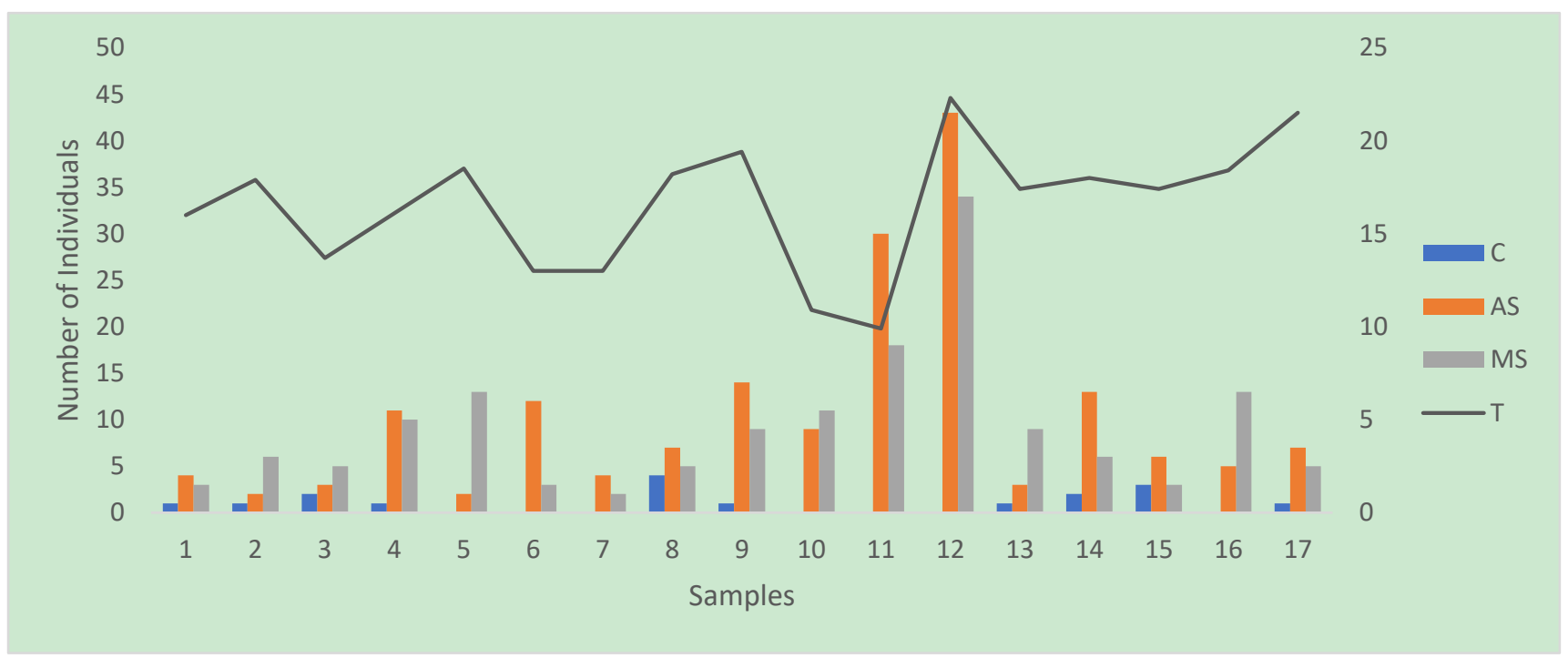

Figure 3. Number of individuals of Scolytinae in relation to temperature.

\section{Discussion}

We can say that the various species of plants available in the agroforest system for these beetles, did not cause a specificity for hosts, unlike the planting of Mimosa scabrella Benth., that there is only one species available for these individuals. There are few studies on the specificity of Corthylus by bracatinga, but the similarity in relation to the abundance and diversity of Scolytinae in the bracatinga and agroforest system areas allows us to establish the hypothesis that the species Mimosa scabrella Benth., probably constitutes a preferentially used plant as host by representatives of the Corthylini tribe in southern Brazil. 
As it is a plant native to this region, it is believed that there is a very close relationship between the Corthylini and this species of host plant. As we can see in graph 3, the highest occurrence of Scolytinae occurred in the months of August and September, when the average minimum temperature was $7.9^{\circ} \mathrm{C}$ and $12{ }^{\circ} \mathrm{C}$, and the average maximum temperature was $19.7^{\circ} \mathrm{C}$ and $22.3^{\circ} \mathrm{C}$, respectively. The distribution of both Corthylini and Mimosa scabrella Benth., seems to be closely linked to low temperatures, both being adapted to this condition.

All species of Corthylus found in the bracatingal are xylomycophagous, as enumerated in the Figure 4: Corthylus ustus (1), Corthylus venustus (2), Corthylus niger (3), Corthylus comitabilis (4), Corthylus nigrescens (5), Corthylus antennarius (6), Corthylus schaufussi (7), Corthylus pharax (8), Corthylus abruptedeclivis (9), Corthylus praeustus (10), that is, the larvae and adults ingest pieces of xylem together with the fungal tissue, and both excavate galleries in the tree (ROEPER, 1995) [6]. In addition, they are frequent in the region and strongly attracted by ethanol. The use of ethanol, a semi-chemical that signals stressed trees, favored the attraction of ambrosia beetles, as they are strongly attracted to ethanol. This may explain, in part, the greater abundance and diversity of xylomycophagous representatives. Ethanol is a chemical signal that indicates to adult beetles and colonizers the location of trees (substrate) ideal for the cultivation of their symbiotic fungi. Despite this trend resulting from the bait used at work, ambrosia beetles are prevalent in tropical and subtropical regions.

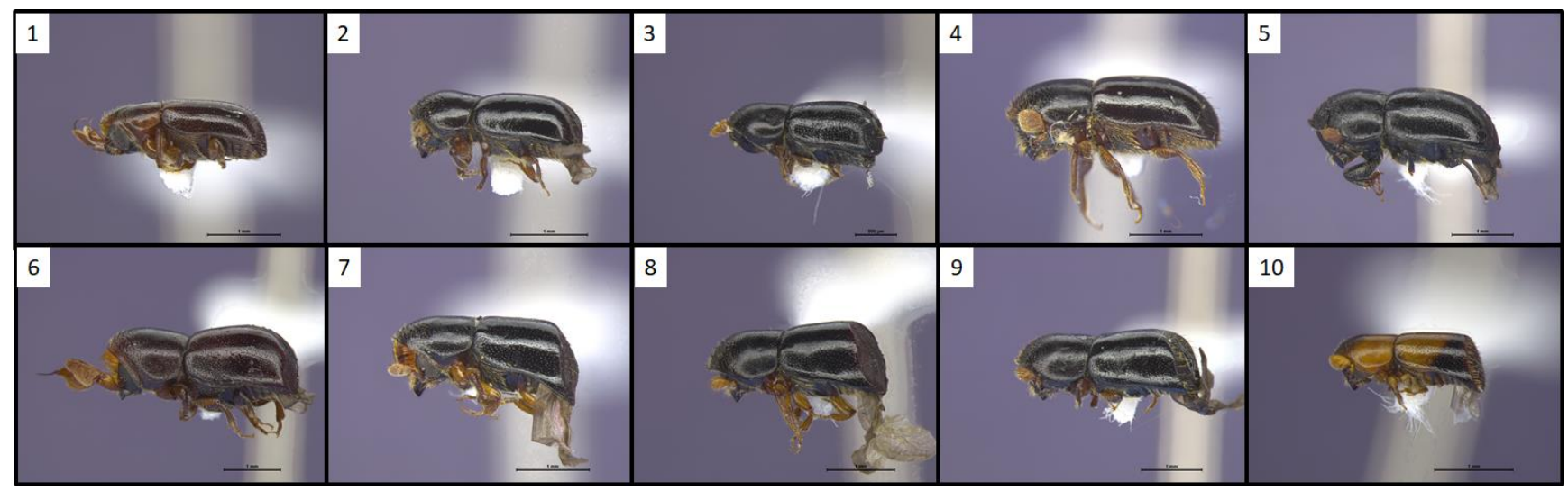

Figure 4. Corthylus xylomycophagous species found in the bracatingal.

\section{Conclusions}

There is little information about the preference of individuals from the Corthylini tribe for hosts, but it is believed that the species M. scabrella Benth., and the species of Corthylus found in the M. scabrella area may be closely linked to low temperatures, being adapted to such condition. In addition, individuals caught in this area are frequent in the region and strongly attracted to ethanol.

The great similarity in terms of the abundance and diversity of Scolytinae between the bracatinga and agroforest system areas allows us to conclude that a landscape with greater plant diversity does not result in a greater diversity of ambrosia beetles. Thus, Corthylini representatives have no potential as bioindicators, which may be related to the fact that these beetles are polyphages.

\section{Author Contributions:}

Funding: This research received no external funding.

Institutional Review Board Statement:

Informed Consent Statement:

Data Availability Statement: 


\section{Conflicts of Interest:}

\section{References}

1. Barbosa, J.S.; Silva, K.C.R.; Carducci, C.E.; Santos, K.L.; Kohn, L.S.; Fucks, J.S. Atributos Físico-hídricos de um Cambissolo Húmico Sob Sistema Agroflorestal no Planalto Catarinense. Floresta e ambiente Seropédica 2017, $24,9$.

2. Castro, J.O.; Teixeira, R.O.; Oliveira, A.D.; Carvalho, A.G. Comportamento de Coleópteros Degradadores de Madeira em Plantio de Mimosa caesalpiniaefolia (sabiá); UFRRJ: Seropédica, Brazil, 2009.

3. Hulcr, J.; Mogia, M.; Isua, B.; Novotny, V. Host specificity of ambrosia and bark beetles (Col., Curculionidae: Scolytinae and Platypodinae) in a New Guinea rainforest. Ecol. Entomol. 2007, 32, 762-772.

4. Instituto de Florestas. Floresta e Ambiente; Universidade Federal Rural do Rio de Janeiro: Seropédica, Brazil, 1998.

5. Miller, D.R.; Rabaglia, R.J. Ethanol and (-)- $\alpha$-Pinene: Attractant Kairomones for Bark and Ambrosia Beetles in the Southeastern; Springer Science + Business Media: 2009; pp. 435-438.

6. Roeper, R.A. Patterns of mycetophagy in Michigan ambrosia beetles (Coleoptera:Scolytidae). Mich. Acad. 1995, $26,153-161$. Available online: https://geoscience.net/research/021/532/021532633.php (accessed on 14 April 2020).

7. Silva, C.A.M.; Trevisan, H.; Souza, T.S.; Carvalho, A.G. Scolytinae (Coleoptera: Curculionidae) em três Fragmentos Florestais da Região de Mogi Guaçu, SP. Coletanea Nacional Sobre Entomologia 3. 2020. Available online: https://www.finersistemas.com/atenaeditora/index.php/admin/api/artigoPDF/39877 (accessed on 20 February 2021).

8. Wood, S.L. Bark and Ambrosia Beetles of South America (Coleoptera, Scolytidae); Brigham Young University: Provo, UT, USA, 2007; p. 900.

9. Wrege, M.S.; Steinmetz, S.; Reisser, C.J.R.; Almeida, I.R. Atlas Climático da Região Sul do Brasil; Embrapa Florestas: Colombo, Sri Lanka, 2011. 